\title{
Pain Management by Retrobulbar Alcohol Injection in Blind Painful Eyes Due to Late-Stage Neovascular Glaucoma
}

\author{
Osman Şalkacı, ${ }^{1}$ Taha Ayyıldız,, Baran Kandemir, ${ }^{1}$ Ümit Çallı, \\ Özlen Rodop Özgür, ${ }^{1}$ Yusuf Özertürk'
}

'Department of Ophtalmology, Kartal Dr. Lütfi Kırdar Training and Research Hospital, İstanbul, Turkey

${ }^{2}$ Department of Ophtalmology, Haydarpaşa Numune Training and Research Hospital, İstanbul, Turkey

Submitted: 04.11.2015 Accepted: 31.12 .2015

Correspondence: Osman Şalkacı, Kartal Dr. Lütfi Kırdar Eğitim ve Araştırma Hastanesi, Göz Hastalıkları Kliniği, İstanbul, Turkey

E-mail: salkacigoz@mynet.com

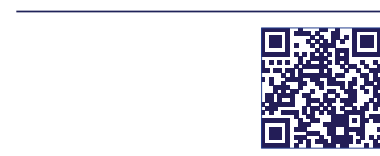

Keywords: Blind painful eyes; pain; retrobulbar alcohol injection.

\begin{abstract}
Objective: This study aimed to evaluate the efficacy of retrobulbar alcohol injections using the verbal analog scale (VAS) in patients with blind painful eyes due to late-stage neovascular glaucoma.
\end{abstract}

Methods: A total of 20 eyes with severe pain due to neovascular glaucoma were injected with $95 \%$ ethyl alcohol in the retrobulbar area. On the basis of the number of injections, the patients were separated into group I (I injection) or group 2 ( $\geq 2$ injections). Pain scores and complication rates were compared between the two groups.

Results: The pre-injection median VAS score was $9.00 \pm 0.61$ with no difference between the two groups. On post-injection day I, no difference was found in the median VAS scores between the two groups, although significant intergroup differences appeared at I and 6 months. Seven patients with VAS scores $\geq 5$ in the follow-up were given additional injections. Four patients whose pain was not relieved after three injections underwent evisceration after 6 months. The median VAS scores were significantly lower in all patients at 12 months compared with the baseline. No difference was observed in the median VAS scores between the groups at the final follow-up. Complications included ptosis in five eyes and severe conjunctival chemosis in nine eyes.

Conclusion: Retrobulbar alcohol injection is a safe and effective method for managing patients with neovascular glaucoma having severe pain that is refractory to medical treatment.

\section{INTRODUCTION}

Trauma is the most common cause of blind painful eyes, but retinal detachment, phthisis bulbi, neovascular glaucoma (NVG), intraocular inflammation, chronic open painful glaucoma, and corneal decompensation may also lead to blind painful eyes as well. ${ }^{[1,2]}$ Eye pain constitutes a significant problem in patients suffering from the aforementioned conditions. The most common complaint is severe pain in the orbital area, which most frequently extends to the forehead and the temple. Moreover, even though vision is already lost, photophobia usually accompanies it.
Topical antiglaucomatous, cycloplegic, or steroid agents and bandage contact lenses are the medical treatment alternatives for patients having severe eye pain. ${ }^{[3]}$ Surgical removal of the eye is a prominent traditional treatment for resistant severe pain, if the level of vision is too poor. ${ }^{[4]}$ However, the local application of some agents for neurolysis can be an alternative treatment if the patient has any psychological or medical concerns or enucleation or evisceration. ${ }^{[5]}$ It has been reported that some agents such as ethyl alcohol, phenol, or chlorpromazine are effective from 2 weeks to 2 years in $30 \%-87 \%$ of the cases. ${ }^{[5-11]}$

This study aimed to evaluate the severity and complications of the retrobulbar ethyl alcohol injection in patients 
having NVG-dependent therapy-resistant severe pain using the verbal analog scale (VAS).

\section{MATERIAL AND METHODS}

This study was conducted at the Kartal Dr. Lutfi Kirdar Training and Research Hospital between January 2012 and October 2013. The Helsinki Declaration criteria were implemented in this study. All the participants were informed about the study, and their written approvals were taken. The ethical committee approval was also taken for this anticipatory study.

Patients having severe NVG-independent pain or vision with minimum sensitivity to light were excluded from the ophthalmological examination. Also, patients using any medicines that might affect their pain scoring or those having chronic diseases such as neuropathy-related thyroid function disorder, vitamin BI2 deficiency, alcoholism, or renal failure were also excluded from this study. Patients were assorted into two groups according to the number of injections given: group $I(n=\mid 3)$ included those given only one injection, and group $2(n=7)$ included those given more than two injections. The pain scores after I day, I month, 6 months, and 12 months were noted and evaluated using VAS. "No pain" was evaluated as 0 , and "maximum pain" as 10 . In the controls, seven patients with a VAS score of 5 or more were injected again, and evisceration was performed in those having resistant severe pain despite re-injection. The median VAS scores of the patients who underwent evisceration were compared with those of other patients at each appointment.

For all patients, the medical procedures were performed in an operation room by a single surgeon. Following sterilization of the surgery area, the visual fixation of the other eye at the nasal position was provided. For anesthesia, 2 $\mathrm{mL}$ of $0.5 \%$ bupivacaine (Marcaine) and $2 \mathrm{~mL}$ of $2 \%$ lidocaine $+0.0125 \%$ of epinephrine $\mathrm{HCl}$ mixture (lidocaine) was injected into the retrobulbar area. The inner orbital pressure was allowed to decrease for next 15 min after retrobulbar block anesthesia, thus helping the patient relax, and then $2 \mathrm{~mL}$ of $95 \%$ ethyl alcohol was injected into the retrobulbar area. For both these injections, the aim was to reach the muscle tissue by passing through the tendon capsule present between the lateral and inferior rectus muscles using a $3.5-\mathrm{cm} 22$-gauge needle from the orbital rim area, which corresponded to the three fourth lateral part of the lid. The piston was retracted and bleeding, if any, was checked to avoid injecting into the intravascular area.

The data were analyzed using the SPSS 20.0 software for Windows (SPSS Inc, IL, USA). Median values were given for statistical analysis because the VAS scores were not normally distributed with the Kolmogrov-Smirnov test.
The Wilcoxon rank-sum test was used for intragroup comparisons, and Kruskal-Wallis and Mann-Whitney $U$ tests for intergroup comparisons. The chi-square test was used for comparing qualitative data, and the statistical significance level was determined as $\mathrm{p}>0.05$.

\section{RESULTS}

A total of 20 eyes of 20 patients who were suitable for this anticipatory study protocol were included in this study. The average age of the patients was $61.25 \pm 17.23$ years (between 24 and 84 years of age). The NVG etiology was commonly associated with proliferative diabetic retinopathy $(n=6 ; 30 \%)$ and central retinal vein thickness $(n=6$; $30 \%)$. After the procedure, the patients were followed up for approximately $12.90 \pm 1.02$ months (12-15 months). The general characteristics of the patients are provided in Table I.

The median VAS score before the alcohol injection was $9.00 \pm 0.61$ (8-10), and no difference was found between the two groups $(p>0.05)$. In the last follow-up, the median VAS score was $1.00 \pm 0.55(0-2)$, which was significantly lower than the pre-injection score $(p<0.00 \mathrm{I})$. The pain score between the groups did not show any difference, and it was quite low in the patients who were given a single injection in the first month $(p<0.05)$. Despite making three injections, evisceration was performed in four (20\%) patients who had resistant severe pain. The VAS score of patients who underwent evisceration was $0.00 \pm 0.50$

Table I. Demographic and medical characteristics of the patients

\begin{tabular}{lc}
\hline $\begin{array}{l}\text { Age (year), mean } \pm \text { SD (min-max) } \\
\text { Gender, } n(\%)\end{array}$ & $61.25 \pm 17.23(24-84)$ \\
Male & $5(75)$ \\
Female & $5(25)$ \\
Diagnosis, $n(\%)$ & $6(30)$ \\
$\quad$ Proliferative diabetic retinopathy & $6(30)$ \\
Central retinal vena occlusion & $3(15)$ \\
Post vitrectomy & $3(15)$ \\
Uveitis & $2(10)$ \\
Tumor & \\
Number of injections, $n$ (\%) & $13(65)$ \\
I injection & $3(15)$ \\
2 injections & $4(20)$ \\
3 injections & \\
Complication, $n$ (\%) & $9(45)$ \\
Chemosis & $5(25)$ \\
Ptosis &
\end{tabular}

SD: Standard deviation; Min.: Minimum; Maks.: Maximum. 
$(0-I)$ at the end of 12 months. In group 2, the median VAS scores in the last appointment were significantly lower than the pre-injection score $(p<0.05)$. No difference was found in diagnostic distribution between the groups $\left(\chi^{2}=2.418 ; p=0.655\right)$, gender $\left(\chi^{2}=0.659 ; p=0.417\right)$, or age $(Z=-0.596 ; p=0.55 \mathrm{I})$. No difference was found in terms of age $(Z=-0.474 ; p=0.836)$, gender $\left(\chi^{2}=0.000 ; p=0.718\right)$, or diagnostic distribution $\left(\chi^{2}=3.333 ; p=0.504\right)$ when the patients who underwent evisceration were compared with the other patients. The VAS scores of the patients before the application and during the follow-up are given in Table 2 , and the comparison of patients who underwent evisceration and other patients is given in Table 3.

As method-based complications were evaluated, an intense conjunctival chemosis was detected in five cases (31.25\%), and it was observed that all the complications were temporary. No significant correlation was found between the complication rate and the number of injections $(Z=0.670 ; p=0.503)$.

The I-day and 12-month pain scores of the patients who were given a single injection were not different from the patients who were given more than two injections $(p>0.05)$. The pain scores at I and 6 months were significantly lower $(p<0.01)$. No difference was found between the two groups in terms of age, gender, and diagnostic distribution ( $p>0.05)$. Similarly, age, gender, and diagnostic distribution of the patients who underwent evisceration were similar $(p>0.05)$. Hayreh emphasized that the most critical condition for the cases with diseases that will cause ocular neovascularization is the caution in terms of complications specific to these diseases. ${ }^{[13]}$

\section{DISCUSSION}

The most common causes that lead to NVG are retinovascular diseases, diabetes mellitus, and ocular ischemia syndrome. ${ }^{[12]}$ NVG has a silent prognosis, and it may end up with a serious loss of vision; treating NVG is a quite hard, unpredictable, and questionable issue.

The first aim of the NVG treatment is to decrease the inner pressure of the eye by applying antiglaucomatous agents to avoid loss of vision, or to use corticosteroids to

Table 2. Pain scoring

\begin{tabular}{|c|c|c|c|c|c|c|}
\hline Pain scoring & Beginning & First day & First month & Sixth month & Twelfth month & $\mathbf{p}^{*}$ \\
\hline All patients & $9.00 \pm 0.61$ & $3.00 \pm 0.92$ & $2.00 \pm 2.53$ & $1.00 \pm 2.91$ & $1.00 \pm 0.55$ & $\begin{array}{c}Z=-3.979 \\
p<0.001\end{array}$ \\
\hline \multicolumn{7}{|l|}{ After injections } \\
\hline \multicolumn{7}{|c|}{ Change in the pain scoring } \\
\hline \multicolumn{7}{|c|}{ Number of injections } \\
\hline I injection & $9.00 \pm 0.64$ & $2.00 \pm 0.96$ & $1.00 \pm 0.66$ & $1.00 \pm 0.80$ & $1.00 \pm 0.49$ & $\begin{array}{c}Z=-3.235 \\
p=0.001\end{array}$ \\
\hline$\geq 2$ injections & $9.00 \pm 0.53$ & $3.00 \pm 0.69$ & $7.00 \pm 1.13$ & $7.00 \pm 3.25$ & $0.00 \pm 0.53$ & $\begin{array}{c}Z=-2.392 \\
p=0.017\end{array}$ \\
\hline $\mathrm{P}$ value $(* *)$ & $\begin{array}{c}Z=-1.183 \\
p=0.237\end{array}$ & $\begin{array}{c}Z=-1.585 \\
p=0.113\end{array}$ & $\begin{array}{c}Z=-3.721 \\
p<0.001\end{array}$ & $\begin{array}{c}Z=-3.143 \\
p=0.002\end{array}$ & $\begin{array}{c}Z=-1.942 \\
p=0.052\end{array}$ & \\
\hline
\end{tabular}

Table 3. Comparison of the patients who underwent evisceration with other patients

\begin{tabular}{|c|c|c|c|c|c|}
\hline \multicolumn{6}{|c|}{ Median Verbal Analog Scale Values } \\
\hline Number of injections & Beginning & First day & First month & Sixth month & Twelfth month \\
\hline I injection & $9.00 \pm 0.64$ & $2.00 \pm 0.96$ & $1.00 \pm 0.66$ & $1.00 \pm 0.80$ & $1.00 \pm 0.49$ \\
\hline 2 injections* & 9.00 & $3.00 \pm 0.57$ & $5.00 \pm 0.57$ & 2.00 & $1.00 \pm 0.57$ \\
\hline Eviscerated patients & $10.00 \pm 0.50$ & $3.50 \pm 0.57$ & $7.00 \pm 0.50$ & $8.00 \pm 0.81$ & $0.00 \pm 0.50$ \\
\hline$P$ value & $\chi^{2}=4.345$ & $\chi^{2}=4.057$ & $\chi^{2}=14.482$ & $\chi^{2}=11.798$ & $\chi^{2}=4.866$ \\
\hline$p=0.114$ & $p=0.132$ & $p=0.001$ & $p=0.003$ & $p=0.088$ & \\
\hline
\end{tabular}

"The patients except those who underwent evisceration; "Kruskal-Wallis test. 
decrease the inflammation if necessary. Moreover, antivascular endothelial growth factors, pan-retinal photocoagulation, photodynamic treatment, cyclophotocoagulation, penetrant glaucoma surgery, or seton implantation can be applied alone or in combination with different success rates depending on the underlying pathology. ${ }^{[14-19]}$ The purpose of this treatment is to increase comfort in patients who do not have an effective vision level. For this, topical steroids and cycloplegics, oral or topical analgesics, and cyclodestruction are the most common methods to be applied. ${ }^{[13,20]}$ In resistant severe pain that cannot be treated with these methods, the surgical removal of the eye either by enucleation or evisceration becomes prominent as a traditional method. weverHo, globe removal is commonly rejected by most of the patients, and this surgery does not guarantee complete elimination of pain. ${ }^{[2]}$ The injection of chemical neurolytic agents to the retrobulbar area is an alternative method for cases having a poor general health status for this surgery or having psychological, social, or religious reasons. ${ }^{[3,5]}$

Alcohol injection to the retrobulbar area came up in the 1900s as an alternative method to enucleation. ${ }^{[21]}$ It was thought to affect both coagulation in the nerve fibrils and damages that emerge with lipid precipitation. The recurrence of the pain is also thought to be related to the level of nerve destruction. ${ }^{[5,22]}$

In the present study, the VAS score decreased significantly with alcohol injection to the retrobulbar area in patients having therapy-resistant pain, and the treatment success showed an $80 \%$ increase $(16 / 20)$, consistent with previous studies. In $35 \%$ of the cases (7/20), re-injection was needed. Despite re-injection, 57\% (4/27) still had pain, and $20 \%$ (4/7) underwent evisceration.

Retro-ocular alcohol application is painful. Therefore, the consecutive application of a mixture of lidocaine and $95 \%$ ethyl alcohol using the same injector is preferred as an alternative method. Since the density of ethanol is lower than that of lidocaine, ethanol is taken into the injector first, and the injector is held perpendicular to the surface (held straight) and pulled slowly to avoid mixing ethanol and lidocaine. The advantage of this method is only one injection with a single injector. ${ }^{[23]}$ The inner orbital pressure was allowed to decrease for next 15 min after retrobulbar block anesthesia, thus helping the patient relax, and then a retrobulbar alcohol injection was given. Previous studies used lidocaine and ethanol injection in the same injector; however, this technique was not included in the present study, as patients reported very severe sharp pain during and after the injection. Although these two methods are different interventions, the comfort and security of patients were higher with the present method. The orbital and occipital pain after the injection was not observed in this study.
Depending on the alcohol and the method used, some potential complications of the method were noted. Alcohol may cause cellulite lid edema and conjunctival chemosis with tissue reaction. It may also cause blepharoptosis and external ophthalmoplegia with motor nerve infiltration. ${ }^{[6,7]}$ However, these complications are usually temporal. They do not need any special treatment and patients often recover in a few days. ${ }^{[5,24]}$ In previous studies, only one case was reported as having permanent ptosis and third nerve stroke. ${ }^{[25]}$ The complications in the present study were ptosis and chemosis, which were compatible with the other complications in the previous studies, ${ }^{[9,20,21]}$ and the patients recovered in I month. Additionally, no permanent complications were reported in the I-year follow-up. No significant relevance was found between the complication rate and the number of injections.

In previous studies, the other agents that were reported to be used for similar reasons were phenol and chlorpromazine. ${ }^{[9-11,25,26]}$ Both of them caused less pain compared with alcohol, and they acted faster in alleviating the pain. ${ }^{[9,11]}$ Very few studies on either alcohol or other neurolytics use are available. The characteristics of neurolytic agents that make them better than other methods are that they are more comfortable, their effect length is shorter, and they are cheaper. Moreover, their complication rates are lower. However, patients should be warned about extraocular muscle strokes, ptosis, and the need for another application.

Consequently, retrobulbar alcohol application is thought to be an efficient and cost-effective method for eliminating NGV-dependent pain. The agent can be changed depending on the availability and the preference of the surgeon. ${ }^{20]}$ In future randomized-controlled studies, it will be beneficial to compare the comfort level and the effect length of the neurolytic agents.

Authorship contributions

Concept: O.Ş., T.A., B.K., Ü.Ç., Ö.R.Ö., Y.Ö.; Design: O.Ş., T.A., B.K., Ü.Ç., Ö.R.Ö.; Data collection \&/or processing: O.Ş., T.A., B.K., Ü.Ç., Ö.R.Ö.; Analysis and/or interpretation: O.Ş., T.A., B.K., Ü.Ç.; References search: O.Ş., T.A., B.K., Ü.Ç., Ö.R.Ö.; Writing: O.Ş., T.A., B.K., Ü.Ç.; Critical review: O.Ş., T.A., B.K., Ü.Ç.

Conflict of interest

None declared.

\section{REFERENCES}

1. Erie JC, Nevitt MP, Hodge D, Ballard DJ. Incidence of enucleation in a defined population. Am J Ophthalmol 1992;113:138-44. [CrossRef]

2. Custer PL, Reistad CE. Enucleation of blind, painful eyes. Ophthal Plast Reconstr Surg 2000;16:326-9. [CrossRef]

3. Shah-Desai SD, Tyers AG, Manners RM. Painful blind eye: efficacy of enucleation and evisceration in resolving ocular pain. Br J Ophthal- 
mol 2000;84:437-8. [CrossRef]

4. Merbs SL. Management of a blind painful eye. Ophthalmol Clin North Am 2006;19:287-92.

5. al-Faran MF, al-Omar OM. Retrobulbar alcohol injection in blind painful eyes. Ann Ophthalmol 1990;22:460-2.

6. Maumenee AE. Retrobulbar alcohol injections; relief of ocular pain in eyes with and without vision. Am J Ophthalmol 1949;32:1502-8.

7. Olurin O, Osuntokun O. Complications of retrobulbar alcohol injections. Ann Ophthalmol 1978;10:474-6.

8. Ferrer-Brechner T. Anesthetic techniques for the management of cancer pain. Cancer 1989;63(11 Suppl):2343-7. [CrossRef]

9. Birch M, Strong N, Brittain P, Sandford-Smith J. Retrobulbar phenol injection in blind painful eyes. Ann Ophthalmol 1993;25:267-70.

10. Estafanous MF, Kaiser PK, Baerveldt G. Retrobulbar chlorpromazine in blind and seeing painful eyes. Retina 2000;20:555-8. [CrossRef]

11. Chen TC, Ahn Yuen SJ, Sangalang MA, Fernando RE, Leuenberger EU. Retrobulbar chlorpromazine injections for the management of blind and seeing painful eyes. J Glaucoma 2002;11:209-13. [CrossRef]

12. Al-Shamsi HN, Dueker DK, Nowilaty SR, Al-Shahwan SA. Neovascular glaucoma at king khaled eye specialist hospital - etiologic considerations. Middle East Afr J Ophthalmol 2009;16:15-9.

13. Hayreh SS. Neovascular glaucoma. Prog Retin Eye Res 2007;26:47085. [CrossRef]

14. Avery RL. Regression of retinal and iris neovascularization after intravitreal bevacizumab (Avastin) treatment. Retina 2006;26:352-4.

15. Parodi MB, Lacono P. Photodynamic therapy for neovascular glaucoma. Ophthalmology 2005;112:1844-45. [CrossRef]

16. Delgado MF, Dickens CJ, Iwach AG, Novack GD, Nychka DS, Wong $\mathrm{PC}$, et al. Long-term results of noncontact neodymium:yttrium-alu- minum-garnet cyclophotocoagulation in neovascular glaucoma. Ophthalmology 2003;110:895-9. [CrossRef]

17. Elgin U, Berker N, Batman A, Simsek T, Cankaya B. Trabeculectomy with mitomycin $\mathrm{C}$ combined with direct cauterization of peripheral iris in the management of neovascular glaucoma. J Glaucoma 2006;15:466-70. [CrossRef]

18. Every SG, Molteno AC, Bevin TH, Herbison P. Long-term results of Molteno implant insertion in cases of neovascular glaucoma. Arch Ophthalmol 2006;124:355-60. [CrossRef]

19. Eid TM, Radwan A, el-Manawy W, el-Hawary I. Intravitreal bevacizumab and aqueous shunting surgery for neovascular glaucoma: safety and efficacy. Can J Ophthalmol 2009;44:451-6. [CrossRef]

20. Kumar CM, Dowd TC, Hawthorne M. Retrobulbar alcohol injection for orbital pain relief under difficult circumstances: a case report. Ann Acad Med Singapore 2006;35:260-5.

21. Çok OY, Eker HE, Cantürk S, Yaycioğlu R, Ariboğan A, Arslan G. Pain management in blind, painful eyes: clinical experience with retrobulbar alcohol injection in 4 cases. Agri 2011;23:43-6. [CrossRef]

22. Skorin L Jr, Briggs KS, Multack RF. Spasmus nutans: a pediatric enigma. J Am Optom Assoc 1986;57:893-4.

23. Maza CE. A safer technique for retrobulbar alcohol injections. Ophthalmic Surg 1989;20:823.

24. May DR, May WN. Decreasing discomfort caused by retrobulbar alcohol injection. Am J Ophthalmol 1983;95:262-3. [CrossRef]

25. Fiore C, Lupidi G, Santoni G. Retrobulbar injection of chlorpromazine in the absolute glaucoma (author's transl). J Fr Ophtalmol 1980;3:397-9.

26. Margo CE, Wilson T. Orbital cellulitis after retrobulbar injection of chlorpromazine. Arch Ophthalmol 1993;111:1322. [CrossRef]

\section{Son Dönem Neovasküler Glokom Hastalığına Bağlı Ağrılı Görmeyen Gözlerde Retrobulber Alkol Enjeksiyonu İle Ağrı Yönetimi}

Amaç: Bu çalışmada, son evre neovasküler glokoma (NVG) bağlı ağrılı görmeyen göz şikayeti olan hastalarda retrobulber alkol etkinliği Verbal Analog Skala (VAS) ile değerlendirildi.

Gereç ve Yöntem: Neovasküler glokoma bağlı şiddetli ağrısı olan 20 hastanın 20 gözünde retrobulber alana \%95 etil alkol enjeksiyonu uygulandı. Hastalar enjeksiyon sayısına I enjeksiyon ve $\geq 2$ enjeksiyon uygulanan hastalar şeklinde iki gruba ayrıldı. Gruplar arasında ağrı skorları ve komplikasyon oranları karşılaştırıldı.

Bulgular: Enjeksiyon öncesi median VAS değeri $9.00 \pm 0.61$ idi ve gruplar arasında farklılık yoktu. Gruplar arasında birinci gün median VAS değerleri farklılık göstermezken, birinci ve altıncı ayda gruplar arasında anlamlı farklılık mevcuttu. Kontrollerinde VAS değeri $\geq 5$ olan yedi hastaya ek enjeksiyon uygulandı. Üç enjeksiyona rağmen ağrısı giderilemeyen dört hastaya altıncı aydan sonra evisserasyon yapıldı. Bütün hastalar için I2. ay median VAS değeri işlem öncesine göre anlamlı şekilde düşüktü. Son kontrolde gruplar arasında median VAS değerleri açısından farklılık izlenmedi. Komplikasyonlar beş gözde ptozis, dokuz gözde yoğun konjonktival kemozis idi.

Sonuç: Retrobulber alkol enjeksiyonu tıbbi tedaviye dirençli şiddetli ağrısı olan NVG'li olgularda ağrı yönetimi açısından güvenli ve etkili bir yöntemdir.

Anahtar Sözcükler: Ağrılı göz, ağrı yönetimi, retrobulber alkol enjeksiyonu. 